\title{
They call them 'good-luck polka dots': disciplining bodies, bird biopower, and human-animal relationships at the Aquarium of the Pacific
}

\author{
Teresa Lloro-Bidart ${ }^{1}$ \\ California State University, Chico, USA
}

\begin{abstract}
The Aquarium of the Pacific is a 501(c)3 institution in the United States, beholden to ticket sales for its survival. In this article I show how its staff, and its animals, co-participate in an "edutainment" project, where the institution governs the bodies of Lorikeets through regulatory technologies crafted to ensure guests have a satisfying experience and become more conservation-minded. In this way, the Lorikeets are politically deployed to support the fiscal survivability of the institution, and in its conservation education project that imagines visitors as "advanced liberal" consumers, insofar as they choose their edutainment experiences and their environmentally responsible behaviors. The resulting guest-Lorikeet interactions promote sanitized encounters with wildness, limiting the development of empathic human-animal relationships. Staff, however, do develop empathic and intersubjective relationships with the birds.
\end{abstract}

Keywords: biopolitics, biopower, green governmentality, human-animal relationships, person-based identification, egomorphism, Lorikeets (Trichoglossus haematodus)

\section{Résumé}

L'Aquarium du Pacifique est une institution 501 (c) 3 aux États-Unis, qui compte sur la vente des billets pour sa survie. Dans cet article, je montre comment son personnel et ses animaux co-participer à un projet dit «edutainment», où l'institution régit les organismes de loriquets par des techniques réglementaires conçus pour assurer aux clients une expérience satisfaisante et de devenir plus soucieux de la conservation. De cette façon, les loriquets sont politiquement déployés pour soutenir la survie financière de l'institution, et dans son projet d'éducation de conservation qui imagine les visiteurs que les consommateurs «avancées», dans la mesure où ils ont choisi leurs expériences de divertissement éducatif et leurs comportements respectueux de l'environnement. Les interactions visiteurs-loriquets résultant de promouvoir des rencontres désinfectés avec la sauvagerie, et a limiter le développement des relations homme-animal empathiques. Cependant le personnel de l'Aquarium ont développent des relations empathiques et intersubjectives avec les oiseaux.

Mots-clés: la biopolitique, biopouvoir, la gouvernementalité vert, relations homme-animal, identification axée sur la personne, egomorphism, loriquets (Trichoglossus haematodus)

\section{Resumen}

El acuario del Pacífico es una institución 501(c) 3 en los Estados Unidos, en deuda con la venta de entradas para su supervivencia. En este artículo muestro como su personal, y sus animales participan conjuntamente en un proyecto de educación y entretenimiento, edutaiment, donde la institución administra los cuerpos de loritos arcoíris (lorikeets) a través de tecnologías de regulación elaboradas para asegurar que los invitados tengan una experiencia satisfactoria y se vuelvan más conservacionistas. De esta manera, los Loritos son desplegados políticamente para apoyar la supervivencia fiscal de la institución, y en su proyecto de educación para la conservación, el cual imagina a los visitantes como consumidores avanzados, en la medida en que eligieron su experiencia de educación y entretenimiento al igual que su comportamiento ambientalmente responsable. Las interacciones resultantes entre visitantes y los loritos promueven encuentros higienizados con lo salvaje, limitando el desarrollo de las relaciones empáticas entre humanos y animales. Sin embargo el personal desarrolla relaciones empáticas e intersubjetivas con los pájaros.

Palabras claves: biopolítica, biopoder, gubernamentalidad verde, relaciones entre humanos y animales, identificación basada en la persona, egomorfismo, Lorito Arcoíris (Trichoglossus haematodus)

\footnotetext{
${ }^{1}$ Teresa Lloro-Bidart, Assistant Professor, Science Education Department, California State University, Chico, Holt 101, Chico, CA, USA. Email: tlloro-bidart "at" csuchico.edu. I express the utmost gratitude to my advisor, Begoña Echeverria, and $\mathrm{PhD}$ dissertation committee members at University of California Riverside, Derick Fay and Farah Godrej, for their expertise. I also thank the staff at the Aquarium of the Pacific and the anonymous reviewers and editors at the Journal of Political Ecology.
} 


\section{Introduction}

The Lorikeet Forest (the Forest) at the Aquarium of the Pacific (the Aquarium) in Long Beach, California is never quiet. Though the number of people in the Forest fluctuates widely, the brightly colored Rainbow Lorikeets constantly chatter, squawk, and fly about at staggering speeds. Their flight pattern is limited, of course, by an overhanging net extending more than 20 feet in the air. In the 3,200 square foot $\left(297 \mathrm{~m}^{2}\right)$ outdoor habitat, they land on (un)suspecting people, on branches of artificially constructed trees, on the ground where they build nests underneath the dirt, and on the wood fence posts demarcating spaces where visitors can and cannot walk (Figure 1). The birds seem most fond of visitors who have purchased "liquid gold"—specially-formulated-to-mimic-nature nectar they slurp up with their evolutionarily-fashioned beaksand on staff members with whom they have developed a special relationship. The number of birds living in the Forest ebbs and flows as sick, injured, old, and aggressive animals are removed from the exhibit to live temporarily or permanently in the Barn behind Shark Lagoon and as new chicks hatch and are released.

Besides visitors who travel in and out of the Forest each day, usually for only a few minutes of time, the Lorikeets also have regular contact with Aquarium staff members, some who become recognizable to the birds. The first few months I ventured into the Forest, like any novice, I would jerk slightly to the right or left as I felt a Lorikeet come rushing toward what I thought was my head. Trained staff explained that when human interlocutors move suddenly, they actually increase the likelihood of a collision occurring. The Lorikeets more deftly avoid crashes with non-moving objects than moving ones, making my sudden movements possibly dangerous for us both. Aquarium staff work tirelessly to prevent these interactions by carefully monitoring, regulating, and surveying both the animals that live at the Aquarium and the over one million guests who visit them each year. The animals also participate as active agents in this monitoring. In this article , I show how the Aquarium, its staff, and its animals, co-participate in an "edutainment" project, where the institution governs Lorikeet bodies through regulatory technologies crafted to ensure guests have a satisfying experience and become more conservation-minded. ${ }^{2}$ In this way, the Lorikeets are politically deployed (Ogden et al. 2013) in the fiscal survivability of the institution and in a conservation education project imagining visitors as advanced liberal consumers, insofar as they chose their edutainment experiences and their environmentally responsible behaviors. The resulting human-Lorikeet interactions promote sanitized encounters with wildness, limiting the development of empathic human-animal relationships. ${ }^{3}$

\section{Conceptual frameworks}

I draw primarily on the work of Foucault and scholars who have theorized the production of environmental knowledge in a Foucauldian framework. Rutherford's "green governmentality," a form of governing that "necessitate[s] its [nature's] regulation and management by particularly located experts" reveals that governmentality and the commodification of nature work in concert to "to produce the truth about nature as not only scientized, knowable, and measurable, but also consumable" (2011: xvii-xix). ${ }^{4}$ Rutherford's model, developed through a media analysis of Al Gore's An Inconvenient Truth movie, and fieldwork at the American Natural History Museum, Disney's Animal Kingdom, and an ecotour to Yellowstone and Grand Teton National Parks, is useful for its conceptualization of the role of scientific expertise in producing knowledge about the environment. However, she does not fully tend to how neoliberal ideologies of choice impact institutional decision-making and knowledge production in informal learning centers, like the Aquarium. As a non-profit institution financially beholden to "program services",

\footnotetext{
2 These disciplinary practices (Foucault 1986, 2003) include: (1) Staff quietly survey and/or verbally admonish guests to regulate behavior; (2) Lorikeets bite, defecate on, and refuse to interact with guests; and (3) The institution requires that Lorikeets be fed a modified diet during the day and that they remain captive. The Lorikeets are managed bipolitically as staff monitor the health and numbers of the population, or "make live", through disease management and breeding practices. I also borrow from Latour (1986), Callon (1986), and Haraway (1989, 2008) implicating not only humans, but nonhuman animals as actors.

${ }^{3}$ In this paper, "sanitized" encounters with wildlife refer to interactions where animal bodies are modified in order to bolster the human experience. The practices include the spatial and bodily regulation of Lorikeet bodies in the Forest.

${ }^{4}$ Rutherford's "green governmentality" is grounded in Foucault's "governmentality", which posits that "power is exercised in multiple sites, through different discourses, and often outside the traditional boundaries of the state." (Rutherford 2011: xv) She notes, "For Foucault, power, and thus the ability to craft particular discourses, is not possessed or held but circulates via networks that work through and produce bodies, subjects, discourses, practices, institutions, and representations." (2011: xxiii)
} 
predominantly in the form of ticket sales, the Aquarium envisions and then caters to a neoliberal environmental citizen (with particular imagined tastes) in order to sustain itself in a capitalistic economy (Carrier 2012). ${ }^{5}$ This citizen is a rational consumer of education, entertainment, and leisure experiences who engages in a kind of cost-benefit analysis in deciding where limited leisure funds will be maximally spent (Fletcher 2010; Lemke 2001). The Aquarium, therefore, seeks to establish a careful balance between promoting its own interests (teaching conservation "science") and appealing to its consumers' perceived tastes. To theorize the role of neoliberal consumer choice, I turn to the work of Rose (1993, 1996), Lemke (2001), and Fletcher (2010) who have collectively developed the notion of neoliberal governmentality drawing on the work of Foucault (1991, 2007, 2008). Fletcher points out:

All of these realms [e.g. politics and social relations] become viewed as spaces, like the market, in which rational actors compete to maximise their use of scarce resources, and thus governance in all such areas should entail the construction of appropriate incentive structures to direct actors' behaviors in beneficial ways (Fletcher 2010: 174).

As I discuss below, precisely because the Aquarium imagines visitors as neoliberal consumers of entertainment and education experiences whose tastes they must accommodate in order to ensure their own prosperity, Lorikeet bodies become enrolled in a biopolitical project necessitating their management and regulation.

Foucault $(1978,2003)$ developed the conceptual tools of bipower and biopolitics in order to explain how, in the nineteenth century, the State began to control the biological in order to "make live and let die", whereas the Sovereign had previously operated through the mechanism of "let live and make die" (2003: 241). He distinguishes between disciplinary technologies (those acting on the individual body) and regulatory technologies (those operating at the level of the population) in order to demonstrate how, after making the management of life a political issue, the State intervened in its regulation. For Foucault, "Biopolitics deals with the population, with the population as a political problem, as a problem that is at once scientific and political, as a biological problem and as power's problem" (2003: 245). In the last two decades, scholars have applied Foucault's biopolitics to the management of nonhuman bodies (Chrulew 2011; Luke 2000a,b; Rutherford 2011).

I first demonstrate that the biological and spatial management of animal bodies, as commodifiable forms of biopower, promote human-in-wild animal theme park relationships. ${ }^{6}$ These institutionally-designed relationships attempt to provide guests with a satisfying experience in order to:

(1) ensure that visitors spend funds at the Aquarium, and

(2) promote the Aquarium's brand of "conservation", i.e. if guests have enjoyable experience they will be more likely to adopt conservation-minded behaviors. ${ }^{7}$

\footnotetext{
${ }^{5}$ In the early 2000s, for example, the LA Times published several articles detailing the Aquarium's fiscal woes (Weikel $2000 \mathrm{a}, \mathrm{b})$. While it was reported that the institution was not in danger of shutting its doors, it was feared the Aquarium would not make its bond payments. As a result, new strategies were implemented to attract additional guests who would provide the needed funding. These included: new displays, more educational programs, increased marketing, doubling after-hours events, and adding more behind-the-scenes tours. While the Aquarium is currently financially solvent, costsaving measures continue. Shark Lagoon and the Lorikeet Forest were recently converted to primarily volunteer staff, rather than paid staff (personal communication). To illustrate the importance of the revenue contributions made by visitors, in 2011 they were as follows: "Program services" i.e. income generated through educational programs (70 percent of total revenue); parking fees and food sales (6.5 percent of revenue); and goods, i.e. items visitors purchase in the Aquarium's gift stores (nearly 7.5 percent of revenue). Collectively, these sources constitute approximately 84 percent of the Aquarium's income (Aquarium of the Pacific 990 Tax Form 2011).

${ }^{6}$ Drawing on the regulation of animal bodies in the theme park atmosphere of the Forest, I call the encounters guests have with the Lorikeets "human-in-animal theme park" interactions. These interactions, as I describe in this paper, are anthropocentric as the animal body is sanitized in order to meet human standards of wild animality in a space like the Forest. Further, because guests have paid not only for the interaction, but for the visit, the interactions are commodified.

${ }^{7}$ Negative experiences, based on interviews with staff and annual Aquarium visitor surveys, include: (1) being defecated on or bitten by an animal; (2) having contact with animal death, sickness, or mistreatment; (3) feeling despair or
} 
I then discuss the how the Lorikeets, as agentic beings, problematize these encounters as visitors and their staff caretakers attempt to manage Lorikeet bodies and behavior. ${ }^{8}$ Like the battery hens and the research scientist studying them in Pedersen's (2010) study, Lorikeets cannot escape their confinement or "forced labour" at the Aquarium, but they can "complicate, disturb, delay, or change the order of the working scheme" (2011: 19). Last, I show how staff engage in an ongoing discplining of visitors, both covertly and overtly, which is heavily dependent on "technologies of vision" (Rutherford 2011) and what I call "technologies of touch." 9

I close by discussing the potential implications of these relationships. The regulation of bird bodies in the Forest is intimately linked to the production of a satisfying experience for guests, imagined as neoliberal consumers of education and entertainment (or edutainment). The goal is to promote what the Aquarium views as a positive encounter for guests, designed to inspire repeat visits and environmentally responsible behaviors (Rose 1993, 1996). ${ }^{10}$ While the institution must fiscally sustain itself through ticket sales, much like the "user fees" sustaining Jamaican parks that Carrier (2012) describes, the short-lived, sanitized, and commodified interactions guests then have with the Lorikeets, which frame human-animal interactions as consumptive, are unlikely to invoke care, compassion, and empathy for nonhuman animals and nature. ${ }^{11}$

To establish a connection between the institution's catering of animal bodies to guests and the kinds of human-animal relationships produced as a result, I look to the work of environmental anthropologist, Kay Milton (2002), who argues that when people have formative emotional relationships with the nonhuman world, they can identify with "other entities" and become empathic not only to nonhuman animals, but also nature more generally. Within the deep ecology framework, identification with the nonhuman world is essential to self realization:

...the deep ecology norm of self-realization goes beyond the modern Western self which is defined as an isolated ego striving primarily for hedonistic gratification or for a narrow sense of individual salvation...the deep ecology sense of self requires a further maturity and growth, an identification which goes beyond humanity to include the nonhuman world (Devall and Sessions 1985: 158).

Building on the work of philosophers like Warwick Fox and Arne Naess, Milton explains that identification happens because western cultures employ a "person-based identification" grounded in the idea that "in order to identify with an entity we must perceive it in something resembling ourselves, in other human beings and in nonhuman entities", though it is also possible to "perceive personhood in other natural entities", besides nonhuman animals (2002: 79). ${ }^{12}$ Milton's framework, useful for its attention to the roles of

culpability for environmental damage; (4) feeling incapable of making positive environmental changes; (5) being scolded by staff; (6) not learning something new; and (7) not having the opportunity to interact with a staff member.

${ }^{8}$ My use of the term "agency" here is not to imply that there is intentionality on the part of the Lorikeets as we would describe human agency. Rather, I utilize "agency" to demonstrate that nonhumans and humans co-produce relationships as they respond to each other's actions, albeit utilizing different means of communication.

${ }^{9}$ Disciplining, as Pachirat (2011) demonstrates in his ethnography of an industrialized slaughterhouse, involves a careful dance of distancing (what is distasteful is kept hidden away) and mediation (power is everywhere and all actors are implicated in it). Desmond (1999) contends that power relationships at zoos and aquariums are often hidden by exhibits that look natural, but I will show that that these relationships are not always covert.

10 The Aquarium's conservation education program includes a heavy emphasis on individual behavioral changes guests can make in their daily lives. These examples abound at the Aquarium and include, but are not limited to: recycling, reducing fertilizer usage, conserving water and energy through a variety of means, and consuming sustainable seafood and/or less meat.

${ }^{11}$ I characterize human-Lorikeet interactions at the Aquarium as commodified because humans must pay for them through an admissions ticket and the purchase of nectar. Additionally, the interaction is packaged a commodity to be sold to guests insofar as Lorikeet bodies are regulated as biopower for that specific purpose.

${ }^{12}$ Milton explains that Fox describes three general kinds of identification with other beings: personally-based (personal involvement with other entities), ontologically-based (realization of a common existence with other entities), and cosmologically-based (we and other entities belong to a 'single unfolding reality') (2002: 78). She argues that Fox's categories are useful, but incomplete, especially for western cultures. Milton distinguishes her "person-based identification" from Fox's "personally-based identification" on the grounds that the former requires personal involvement, while the latter depends only on a sense of similarity (2002:79). She adds to the work of Naess and Fox by highlighting 
experience and emotion in developing empathic relations with animals, falls short with respect to two key points, however: (1) Milton (2002, 2005) fails to consider how the condition of the nonhuman impacts the kind of personal experience a person can have in a particular environment and (2) Milton (2002, 2005) does not fully develop the degree to which humans can identify with other entities through the recognition of negative attributes or emotions. I argue that the anthropocentrically-orchestrated encounters visitors have with Lorikeets at the Aquarium (bipolitically-fashioned to please the envisioned neoliberal consumer) indeed provide experiences with wildlife. The quality of these encounters, however, is limited in that the experiences of the Lorikeets themselves are muted to privilege the guest experience. I also show how some staff members, despite the institution's belief that humans (i.e. visitors) ought to encounter Lorikeets in a sanitized fashion, accept the "negative" aspects of wildness, such as biting and defecating, and come to view the Lorikeets as "like me." Other staff reconcile these aspects of wildness through constructing a romanticized wild "other" they view as not "like me."

\section{Exhibit background}

In 2003, five years after the Aquarium opened, the Lorikeet Forest was constructed. Originally a lush, green, and forested aviary, the habitat now appears denuded, with constructed "trees" pieced together from dried out branches anchored in the ground and covered with ground cover, pebbles, and grass to appear natural (Figure 1). From these "trees" hang bird toys resembling those a pet bird owner would seek in a pet store. According to an Aquarium staff member, birds destroyed the live trees originally present in the Forest and they had to be removed. The Forest floor consists of a concrete pathway where guests are permitted to walk, flanked on both sides by guest-forbidden areas. Lorikeets generally build their nests in these spaces, either in the ground or in the provided nesting boxes.
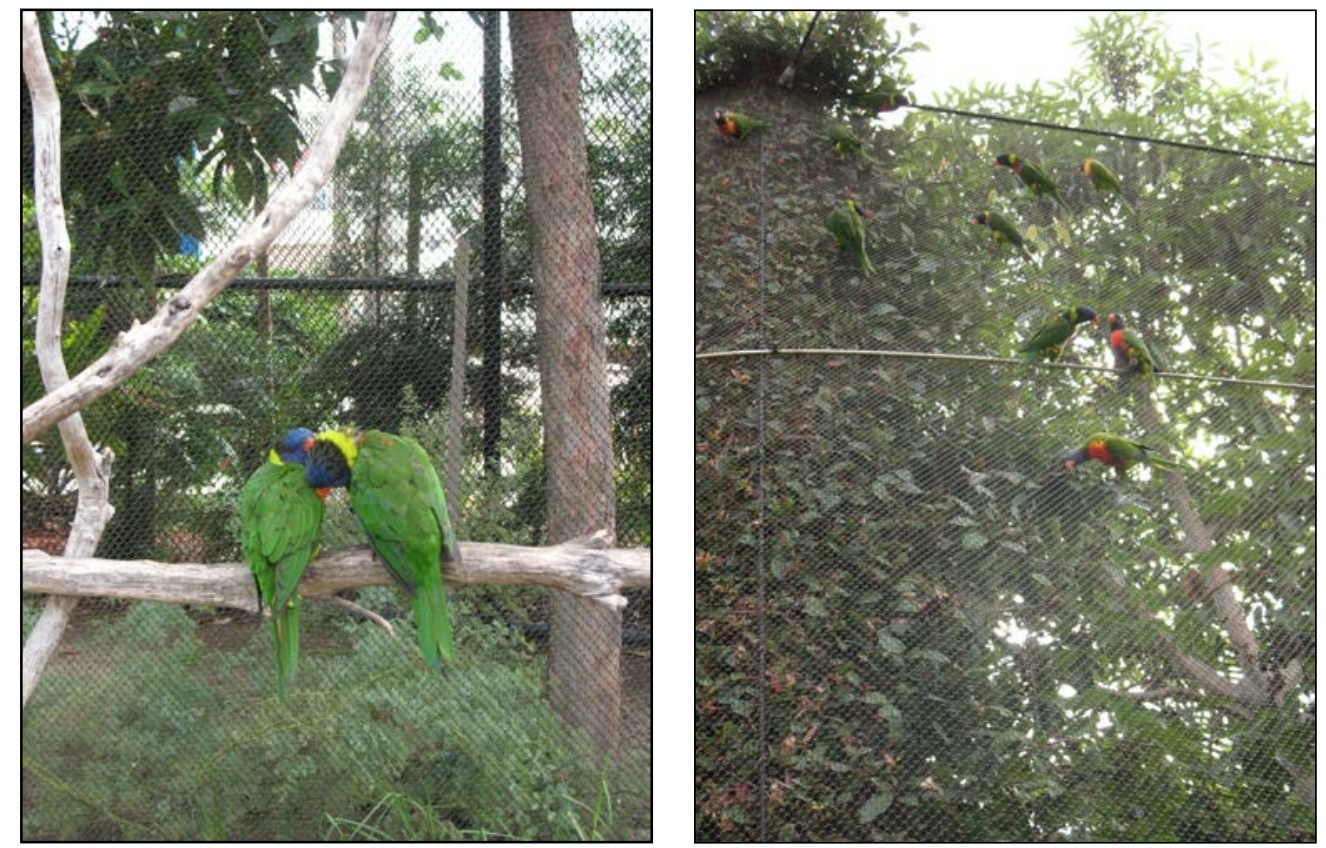

Figure 1: Lorikeets at the Aquarium. Source: author.

the role of emotion in deep ecology's "self-realization" and by arguing that the belief that all entities have a right to selfrealization is ground in the "quality of selfhood" they share with human beings (2002:84). Milton's work adds elements of what she calls "egomorphism" (seeing other entities as "like me") to deep ecology's "biocentrism", in the sense that she, like Williams (1980) and Marietta (1995) wants to put humans back in "nature", though Milton seeks to accomplish this task through the emphasis of emotional connections and person-based identification (Milton 2002, 2005). 


\section{Lorikeet natural history}

The exhibit features five subspecies of Rainbow Lorikeets of 22 subspecies that exist in the wild. According the International Union for Conservation of Nature (IUCN), Rainbow Lorikeets (Trichoglossus haematodus) are a species of Least Concern due to their large range and population size, despite declining populations and the fact that since 1981, when they were listed on CITES Appendix II, over one hundred thousand individuals have been recorded in international trade. ${ }^{13}$ Rainbow Lorikeets are native to Australia and the South Pacific and are considered pests in Western Australia (Massam and Mawson 2009). ${ }^{14}$

\section{Staffing the forest}

Forest staffers are either part of the Husbandry or Education team. As their department titles suggest, the former are mainly responsible for animal care, though they may occasionally interact with guests and do some teaching. Due to their role in animal care and time spent with the animals, Husbandry staff tend to get closer to the animals than Education staff; they know the animals' names, can recognize them and distinguish them from similar members of their species, and, in some cases, have developed relationships with them. Education staff manage visitor behavior, talk with guests over the microphone about basic Lorikeet facts, and have conversations off microphone with smaller groups of guests (what the staff members refer to as "interpretation or "interp" time." $)^{15}$ Education staff typically work 30-minute shifts at one exhibit before rotating to another exhibit, which limits their opportunity to spend time with animals at any given location.

Both the Education and Husbandry departments are comprised of paid and volunteer staff. All staff who work on the floor (regardless of their department and status as paid or volunteer) are visually distinguished from visitors by their blue shirts (usually emblazoned with the Aquarium logo), khaki pants, white sneakers, and white socks. Husbandry staff often don rain boots because they have to tread through watery areas behind the scenes or in exhibits. The paid staff have formalized training in their field (either aviculture for the Husbandry staff working with the Lorikeets and science and/or education for the Education staff), tend to work a semi-regular schedule, and are usually present more often than volunteers, who typically only work the same day of the week each week. The volunteer staff are sometimes formally trained in their departments through prior education or work experience, but often the only training they receive is that provided by the Aquarium. There are Education volunteer staff on each day of the week who refuse to work in the Forest, mostly because they do not care to be defecated on or to get bitten. Paid Education staff generally do not enjoy the right of refusal.

\section{Methods}

I conducted a semi-structured 14-month ethnographic field study (Spradley, 1979) at the Aquarium of the Pacific in Long Beach, California. I interviewed 19 paid staff members and 19 volunteer staff members. Five of these staff members were re-interviewed near the conclusion of the study to verify findings and to look for disconfirming evidence. Most interviewed staff were primarily associated with the Education Department, though several also had roles in Husbandry. During the last month of the study (August 2013), I conducted follow-up interviews with several key informants working in both Education and Husbandry (with the Lorikeets). I also interviewed 28 visitors, in pairs or groups of three, also utilizing semi-structured interviews.

I participant-observed in the Forest one to two times per week from November 2012 to March 2013, at which point I tapered observations to once or twice per month, due to repetition of findings. With their

\footnotetext{
13 The IUCN defines a species of Least Concern in the following manner: "A taxon is Least Concern when it has been evaluated against the criteria and does not qualify for Critically Endangered, Endangered, Vulnerable or Near Threatened. Widespread and abundant taxa are included in this category." (http://www.iucnredlist.org/static/categories_criteria_3_1). Other Lorikeet species are variously listed as Critically Endangered, Endangered, Threatened, Vulnerable, or of Least Concern.

${ }^{14}$ http://www.iucnredlist.org/details/160032124/0

15 Though the Aquarium does have what they call live animal "shows", the talking over the microphone in the Forest is not considered a show, as there is no specific time of the day the talks take place and there is no set script, like in the Seals and Sea Lions or Otter Shows. During these live "shows", Husbandry staff in other departments also co-present with Education staff.
} 
consent, I also audio-recorded conversations with staff in the Forest; these observational recordings and interview recordings were later transcribed and analyzed. ${ }^{16}$

\section{Brightly colored birds as biopower: biological and spatial management as "edutainment"}

Staff overwhelmingly believe visitors come to the Aquarium to be entertained, primarily through interactions with animals and staff. These assumptions are grounded in evidence from annual Visitor Survey Reports, where guests during the summer of 2013 cited entertainment (94 percent) and interest in marine life (86 percent) as their top reasons for visiting, followed by education (52 percent). ${ }^{17}$ Education, therefore, is often "slipped-in" and related to the entertaining experience. The institution and its staff postulate that guests, envisaged as neoliberal consumers of edutainment experiences "seeking to fulfill themselves with a variety of micro-moral domains or 'communities"', will not return to spend additional funds if dissatisfied with their Aquarium visit and may also share their discomfiting experiences with others (Rose 1996: 57). As such, guests are thought to engage in ongoing cost-benefit analyses as they decide where their leisure and education dollars will be disbursed (Fletcher 2010; Lemke 2001). This knowledge, as I describe further, drives many decisions concretely affecting the lives of the Lorikeets as the institution and its staff manufacture the kinds of human-animal interactions they believe visitors desire.

When visitors approach the Forest, two Guest Services volunteer staff members greet them. One monitors the entrance and the other stands behind what looks like a tiki bar at a tropical island getaway. Rather than advertising nightly drink specials, however, this one displays a sign that reads "Feed nectar to the birds" or "Alimente los periquitos con nectar", "\$3." ${ }^{18}$ Another sign to the left, entitled "Lorikeet Hunger Meter", indicates to visitors how hungry the birds are; one to the right lists the over 50 ingredients found in the nectar, specially prepared by Husbandry staff to "mimic nature."

Besides the ticket (or membership) that guests must purchase to gain entry into the Aquarium, the purchase of nectar represents the first commodifiable and regulated interaction they can have with the Lorikeets. By selling the nectar to guests, the Aquarium gains financially and, in effect, controls humananimal interactions - only those guests who choose to purchase it typically have body-to-body contact with the birds. The Lorikeets do not usually land on humans (unless they have food) and visitors are not allowed to grab, touch, or otherwise force physical interaction. The nectar, therefore, becomes the tool to facilitate contact. As Desmond explains in her text Staging tourism, animal reliance on people for food in zoos and aquariums is typical, despite the attempt to create a space that seems "natural." She comments:

The illusion is that we are seeing not only authentic animals but authentic performances of species-species behavior as well. In fact, what we do see in this display of wildness is a display of total dependence on humans for food, care, protection, and survival (Desmond 1999: 164).

Unlike most zoo and aquarium exhibits, the Forest Lorikeets become totally dependent not on their usual staff caretakers, but on visitors seeking a short-lived experience with wild animals. ${ }^{19}$

To ensure guest satisfaction, as a staff member shared with me while she worked inside the Forest, exhibit Lorikeets are fed nectar during the day to make their feces water-like and less viscous so that when

\footnotetext{
${ }^{16}$ While observing, audio-recording, and writing fieldnotes, I paid particular attention to Lorikeet-staff, Lorikeet-visitor, and staff-visitor interactions, drawing on work in multispecies ethnography (Kirksey and Helmreich, 2006; Ogden et al. 2013). I also made note of how the physical surroundings and built environment enabled and constrained interactions. To verify and augment my findings, I analyzed the Aquarium website, tax forms, online newspaper articles, printed visitor guides, the mobile application visitor guide, placards outside and inside the Forest, and staff training materials.

${ }^{17}$ In addition to the statistics cited in the text, in the Summer of 2013 guests also cited the following reasons for visiting the Aquarium: sightseeing (70 percent); curious to see (62 percent); bring children (57 percent); other (18 percent); because I'm a member (16 percent). (Aquarium of the Pacific Summer Survey Report 2013).

${ }^{18}$ Lorikeet bodies also generate revenue for the institution through nectar sales. In 2011, nectar sales earned $\$ 389,454$ for the Aquarium, which constitutes 2\% of Program Services revenue and 1.4\% of total revenue (Aquarium of the Pacific 990 Tax Form 2011).

${ }^{19}$ Knight's analysis of monkey parks in Japan revealed a similar phenomenon. Visitors there enter into a food exchange with monkeys, producing human-animal interactions that would be impossible without food (Knight 2005).
} 
they defecate on unlucky visitors, it makes it less likely their momentary animal companions will offend them. In addition, the nectar is a lighter meal that does not fully satiate the birds. This allows a greater number of guests to purchase nectar and have interactions with the Lorikeets the institution imagines they crave. The Aquarium, by specially designing this meal to make the birds' feces less offensive and then selling the nectar to guests, regulates the Lorikeet population on display in the Forest as a form of biopower, controlling and commodifying both the birds and the human-animal interaction. Regulation of bird bodies not only "makes live", but supports the economic survivability of the institution (Fletcher 2010). Through this physiological modification the Aquarium produces a "sort of body", for guests, utilizing waste "rendered [almost] invisible" as one of the key ordering principles (Anderson 1995: 642, 645). Though Foucault theorized biopower specifically as the regulation of human bodies in the interests of the state and the so-called "common good", (Rabinow 2010) the Aquarium's regulation of animal bodies and human bodies figures prominently into the commodification of nature for human consumption as Aquarium guests are imagined to seek a wild, but not too wild encounter with animals and nature. Therefore, bird bodies, as biopower, provide a two-fold benefit for non-profit institutions like the Aquarium:

(1) they participate in making the Aquarium financially solvent in a capitalistic economy through governing visitors as consumers with choices, and;

(2) they satisfy the guest desire to have an encounter with nature, which the Aquarium presumes will assist in conveying its educational messages.

In an analysis of the shift of zoos (and aquariums) from institutions that promoted the visitor "gaze" to institutions dedicated to education and entertainment, Beardsworth and Bryman (2001) point out that wild animals in zoos and aquariums are "sanitized" in what they call the process of commoditization. Through spatial and bodily regulation the Aquarium packages the birds as an interactive (and not just visual) product that can be sold to guests for financial gain. Though the habitat and their food have been constructed to mimic nature, elements of true wildness are missing there. Unable to forage, the birds become dependent on humans for food; they cannot fly about and seek a mate elsewhere, so they must choose a mate from the other birds in the Forest; and they have become, over time, habituated to the presence of human beings.

\section{Lorikeets discipline their human companions}

The prior section described how the Aquarium offers guests access to some of the untamed, savage, and unpredictable aspects of nature they are presumed to desire, but in an anthropomorphized and restrained way as bird bodies are bioregulated to fiscally benefit the institution. Lorikeets, as wild living beings, however, often complicate this regulation. They bite staff and guests, refuse to land on visitors (sometimes even those visitors who have purchased nectar), and they continue to defecate, despite strictly consuming nectar during the day. These forms of Lorikeet "resistance", as demonstrated below, sometimes complicate visitor, and even staff, satisfaction.

\section{Be careful! They might bite!}

On a busy day, one can spy rows and rows of strollers parked in front of the doors of the Forest, many overflowing with all of the typical accoutrements of American toddlers and their parents-toys, blankets, baby wipes, spare diapers, rattles, and spare items of clothing. I asked a volunteer educator in an interview to talk about her role at the Aquarium and she explained that some years ago management staff decided strollers pose a hazard inside the habitat. Lorikeets can unknowingly crawl into the carriage of the strollers, requiring an unlucky staff member to remove them. This has resulted in bloody encounters with the birds in the past. As a result, the staff member at the entrance of the Forest informs guests with strollers that they must leave them outside and shows them where they may be parked. Guests who choose not to comply cannot enter. Lorikeet biting, therefore, serves as a mechanism to regulate human behavior. People wishing to have physical contact with the birds, or simply venture into their home must abandon their strollers outside the habitat or be denied the opportunity to interact. 
The threat of being bitten also deters some staff members from taking a shift in the Forest. In an interview Rose, a staff member, describes being savagely and repeatedly bit by a Lorikeet one day as she accidentally stepped on its nest. She justifies the bloody encounter as not the fault of the Lorikeet, but rather due to the unnatural human-wild animal physical contact that takes place in the Forest as birds attempt to carry out their normal activities (nesting), despite continual intrusion by humans. Notice how she cites lacking the ability to mistreat the bird (partly because guests are watching), despite being in physical pain:

Excerpt 1.1: October 26, 2012

Teresa: Is there any exhibit that you won't go to?

Rose: The Lorikeets.

I laugh because everyone seems to have a strong opinion about the birds.

Rose: I was attacked. And it was my fault. This is called getting used to the fact that these are wild animals and they do have their patterns of behavior and getting to understand them and I was in there and I stepped in front of a brood box that had a pair inside, a breeding pair, and the male didn't like that and he came out and attached himself to my ankle. And it drew blood. And you have to be really professional. I know I'm free [she's a volunteer staff member], but I still have to be professional.

She goes on to explain that she still loves birds and even shows me a piece of "bird" jewelry she likes to wear. However, due to her bloody interactions, Rose no longer takes shifts in the Forest.

Rose's case illustrates that the packaging of human-Lorikeet interactivity requires a kind of bioregulation that renders Lorikeet bodies consumable; as vital, living beings however, they are not entirely manipulable. In contrast to Luke's (2000) historical analysis of the Audubon Society, which, through "technologies of Audubonization", constructed an innocuous, anthropomorphized, and romantic vision of wild birds so that people would "care" about and want to protect them, the Aquarium constructs a beautiful Lorikeet, but certainly not a defenseless one, given the continual warning that birds may bite and the stories above illustrating that they have bitten in the past. Whereas the Society sought to modify human-animal interactions through advocating gazing upon and photographing aesthetically pleasing and gentle creatures (i.e. there would be no body-to-body contact with live or dead animals, only "technologies of vision"), the Aquarium actually promotes body-to-body contact ("technologies of touch") and therefore sanitizes those aspects of wildness (spatial and biological) amenable to regulation, while simultaneously warning humans of non-regulable aspects (i.e. biting). These "technologies of touch" aim to provide visitors with satisfying experiences at the Aquarium so that they will contribute to the fiscal survivability of a non-profit institution indebted to ticket sales for funding in a capitalistic economic structure.

\section{They just won't land on me!/Get these birds OFF of me!}

At any given time, birds continually fly about and land on trees as they feed, groom, nest, and occasionally, depending on the season, mate. As guests make their way through the habitat, some stop to take photos with the Lorikeets or film them as they carry out their daily activities, others stop to read the placards flanking each side, and those who purchase food attempt (usually successfully) to feed them. While some visitors are bombarded with Lorikeets as soon as they enter with food, others must be more patient in order to have their desired interaction. The prohibition on touching lessens the likelihood that the Lorikeets will bite guests and ensures that guests do not improperly handle the Lorikeets. Guests may attempt to feed the Lorikeets; however, the decision to land on a human and sip up nectar is entirely up to the individual bird. If the Lorikeets are not hungry or seem disinterested in food, the visitor must seek out more famished birds and wait for physical contact. The Lorikeets, in this way, participate actively in creating the kinds of interactions guests can have with them, i.e. the actual interaction is also Lorikeet-driven. This happens despite the Aquarium's attempt to spatially regulate and manage the Lorikeets to make them more accessible and acceptable to guests who have paid for certain kinds of interactions. 
Conversations with guests indicate their cognizance of how the birds mediate their interactions. In this interview, I chat with Jose and Leticia, a young married couple with children, inquiring about the exhibits they visited:

Excerpt 1.2: February 12, 2013

Teresa: Oh you went in the Lorikeet Forest?

Jose: Yeah. And we got to feed them, too with the special liquid. I don't know what it was.

Teresa: Did you guys get to touch them at all?

Jose: Actually, when you touch them they kind of go to the side and they kind of want to fly

away. But I managed to kind of touch one while it was eating.

Teresa: So you had the food? Did you have the food in your hand and they ended up in your arm?

Jose: Yeah. You have to grab it like an ice cream cone (he shows me with his hands and arm). And you have a little, yeah, and they just come to you. They just fly and go to you.

Leticia: It was funny cuz, like, I wouldn't like go to them. I don't know. They would like push me and they would land on top of me.

Jose: Yeah see. They were flying to her. And I was right there alone. And then I got like four of them coming to me. So I had a bunch of birds on me.

The above passage illustrates that most guests, as they traverse through the Forest, have understood how to feed the birds, realize the interaction is Lorikeet-dependent, and are willing to be patient. Most guests do not, however, interact with a staff member who has knowledge about the birds; there is no forum for guests to question why the birds are held captive; guests are not involved in animal rehabilitation; and guests are not aware that their feeding the birds often disrupts Lorikeet territorial behaviors.

\section{Good luck polka dots}

In The history of sexuality Foucault (1979) discussed the State's regulation of bodies in the name of health and hygiene (among other state projects). In modern society, hygiene has come to mean maintaining the body as clean and therefore free of potential disease-causing agents, many of which are associated (rightly or wrongly) with feces (Curtis and Biran 2001). Many guests and staff, therefore, have developed a cultural aversion to feces. The threat of being defecated on is large enough that some volunteer educators refuse to take a shift inside the Forest, despite the fact that the paid staff members who supervise volunteer training ask volunteer staff members-in the-making to convince guests that Lorikeet poop is innocuous because "It's just nectar. So they shouldn't feel bad because it would be worse if they pooped out fish." The "threat", of course, is nothing new, as the theme of avoiding bird poop occurs in countless films, novels, and cartoon strips and recently became a concern due to avian flu epidemics caused, in part, by humans who had contact with infected bird feces. An online search of "bird poop" reveals myriad sites dedicated to selling cleaning products specially designed to remove the feces and halt damage to paint (on cars, for example) or clothing.

Kristal, a volunteer staff member refusing to work in the Forest explains that the bird feces damage clothes:

Excerpt 1.3: October 27, 2012

Teresa: No birds for you either?

Kristal: No.

Teresa: Did you have a bad experience with the birds or you're just not into the birds?

Kristal: I'm not into poop. These guys projectile poop.

Teresa: Yeah.

Kristal: At least 12 feet. It's got a bleach-like quality. So, most of the people that work in there have these little white spots on there, bleach-outed. Good luck polka dots they call them. 
While staff members like Kristal refuse to work in the Forest, some staff and guests do take chances. Below, Sydney and Cisco, both first time visitors, discuss how they do not mind the feces; to them it's what one expects in an interaction with an animal. They express, however, being slightly uncomfortable with how fast the body-to-body and feces-to-body contact took place once they were inside. Lorikeets, as captive wild animals, can exercise agency and moderate human behavior, vis-à-vis these interactions:

\section{Excerpt 1.4: March 6, 2013}

Teresa: Oh you did? So could you tell me about what happened when you guys walked in [to the Forest] and you had the food in your hands, like tell me about your experience in there? Cisco: I got attacked as soon as I walked in. A bird already got on me and did his duty on me and then he took off after that (laughing).

Teresa: Oh. Did he poop on you?

Cisco: (laughing) Yeah.

Sydney laughs, too.

Teresa: So did you know going in they were probably going to land on you since you bought food?

Cisco: Yeah.

Teresa: So you were comfortable?

Sydney: Not that fast, though.

Teresa: Not that fast?

Cisco: I knew it could've happened.

Teresa: And you were okay with being pooped on?

Cisco: Yeah. It's just a bird. That's what he does.

Other visitors, like Paula, Stacey, and Bobby, tread lightly into the Forest. Stacey, a college student, and Bobby, a senior in high school, visited the Aquarium with a family friend they called Aunt Paula. It was their first visit, but Paula had been several times prior. For them, refusing to purchase nectar decreased the likelihood of being defecated on:

\section{Excerpt 1.5: February 23, 2012}

Teresa: It was crowded. Yeah. Did you guys actually interact with the birds? Did you buy the food and have them land on you?

Stacey: We just took pictures.

Teresa: Not really into having the birds land on you?

Paula: Not into having birds poop on us.

They all laughed.

Thus, despite the Aquarium's goal of regulating Lorikeet bodies as biopower through feeding them a special diet during the day in order to ensure customer satisfaction and fiscal survivability, bodies still must defecate. Waste, in this context, cannot be completely "rendered invisible" (Anderson 1995: 645), so guests (and staff) must ultimately confront feces. ${ }^{20}$

\footnotetext{
${ }^{20}$ As the staff members and Aquarium guests cited above demonstrate, no universal "modern attitude" toward bird feces exists. Attitudes toward "matter out of place" (i.e. dirt, excrement, menstrual blood) have been variously shaped by constructed categories that are "public matters" (Douglas 1966: 36-41). In The civilizing process, Elias (1978) traces the history of development of aversions to "natural functions" that increasingly became isolated from public view. This concealment occurred through complicated processes of social change whereby it became largely inappropriate to defecate, urinate, flatulate, or belch in public in Western societies. Therefore, some "modern" Aquarium guests, though seeking contact with "wildness", expect a sanitized version that will not upset their notions of contemporary "dirt" avoidance, systemically tied to hygiene, aesthetics, knowledge of pathogenic organisms, and more importantly, for Douglas, notions of "matter out of place" (1966: 36). However, as some of the interview excerpts above illustrate,
} 


\section{7. "STOP THAT! DON'T DO THAT!" and "Keeping an eye on the kids"}

Forest staff engage in multiple forms of disciplining visitor behavior. They gaze over guests as if security or police officer, surveying their actions. Some staff members actually describe their roles as "babysitters" or "policemen." When necessary, they respond to inappropriate actions in multiple ways, including polite or scathing verbal admonitions followed by explanations as to why the behavior is inappropriate and, very rarely, by using their own body as a means to grab the attention of the offending visitor. In order to ensure a satisfying experience for visitors, staff are trained that the primary means they should interact with guests is through politely and positively suggesting correct behaviors, rather than scolding them for improper actions. While Education staff on the microphone may appear to be giving visitors a "show" or Husbandry staff feeding the birds in the Hut may seem as though they are not paying attention to guests as they bustle about, they are constantly surveying guest behavior. During my time at the Aquarium I did not observe any staff overtly scolding guests, though several told stories of when they felt compelled to utilize more forceful means. Institutionally, these actions are undesirable because they are believed to negatively affect the guest experience and could, therefore, fiscally harm the Aquarium. In this way, staff, like Lorikeets, are carefully managed in order to cater to a neoliberal consumer of edutainment experiences who sustains the institution through ticket sales and other purchases. The following excerpt depicts a conversation I had with Sharon and Jennie in the Forest one morning. Since both have worked in the Education and Husbandry departments, I asked them to describe how those roles might be different, since several staff members had shared each department follows different unwritten rules:

\section{Excerpt 1.6: December 6, 2012}

Sharon: We're [Husbandry] expected to be diplomatic, but if it comes between an animal being injured and a guest having a good experience, we pick the animal.

Jennie: And the Education people are a little more reluctant to do that because they...

Sharon: They get in trouble if they do. That's the thing. They're not supposed to.

Jennie: We're supposed to be diplomatic, too. And I try just as hard to be diplomatic in Husbandry as I do in Education, but to be honest with you I will honestly, hands down, protect the animal and try not to, I try to make the guest, nothing negative with the guest, but if it comes to I have to chose - oh well. I'm not going to let the animal get hurt.

Note that in the above passage, both Sharon and Jennie acknowledge the importance of "being diplomatic"; in another excerpt Sharon discusses avoiding "customer complaints." These examples illustrate the tension at the Aquarium between privileging the experience of guests (neoliberal consumers of edutainment experiences) versus that of the Lorikeets. In this space, the typical visitor "gaze" upon confined wild animals (Desmond 1999; Milstein 2009) has metamorphosed into a different kind of asymmetrical human-animal interaction (Haraway 2008) that seemingly necessitates third-party regulation. Guests crave a short-lived interaction with the "wild", which the institution heavily promotes, but is challenged to do in prescribed and regulated way in order to ensure the safety of the Lorikeets. The institutional focus on guest satisfaction, driven by the Aquarium's fiscal requirements, is anthropocentric as it constructs an experience designed to meet human needs and wants (Devall and Sessions 1985; Watson 2008). Through bioregulating and commodifying animal bodies and nature (Rutherford 2011), the institution hopes to guarantee its own existence. The staff who work directly with the birds in the Forest, however, embrace a different approach and view themselves as "protectors" of the animals, as I describe in more detail in a later section.

As the Aquarium utilizes processes of concealment and visibility (surveillance), guests become subjects able to come to know particular kinds of Lorikeets (healthy, vibrantly-colored birds with watery feces who will land on people carrying cups of nectar), but not others (sick, injured, ill, aggressive, nesting, or juvenile animals). ${ }^{21}$ Staff disciplining and surveying of guests is essential to this process. Were guests to

particularly that of Sydney and Cisco, bird feces do not put off all Aquarium guests. The Aquarium as an institution assumes, though, that most guests would be offended and regulates bird bodies as a result.

${ }^{21}$ Recall that ill, injured, or uncooperative Lorikeets (those who regularly bite staff members) are hidden from guests either in the Hut or the Barn. In this way, the process is similar to that of the industrialized slaughterhouse described by 
break the rules, they might come to know the Lorikeets in ways not fashioned by the Aquarium. Though staff are the experts in this space because they have institutional authority and knowledge of the Lorikeets, they alone do not produce a satisfying experience. The Lorikeets themselves also participate in this process. In the Forest, the spatial availability of healthy and "happy" Lorikeets the spatial isolation of those birds who do not conform to the ideal (recall that injured, ill, or uncooperative animals are concealed from guests), and staff surveillance of guests and animals work in concert to co-produce wild animals fit for human consumption in a theme park atmosphere. Vis-à-vis biopolitical regulation of bird bodies and "act[ing] upon them [visitors] through shaping and utilizing their freedom" (Rose, 1996, p. 54) the Aquarium packages a sanitized encounter with nature designed to promote its own institutional viability and conservation education project.

\section{Forging human-animal relationships at the Aquarium}

Zoos and aquariums have endured sustained criticism because they have historically encouraged visitors to "gaze" over captive wild animals in simulated habitats (Beardsworth and Bryman 2001; Milstein 2009), encouraging the Cartesian separation of humans and nature (Milton 2002, 2005; Williams 1980). The Aquarium, therefore, seeks to address this criticism by imagining a neoliberal consumer of environmental edutainment experiences craving to put the "human" back in "nature" through nonhuman and human body-tobody contact. Their goal is to deliver this contact while simultaneously ensuring their own prosperity. However, body-to-body contact cannot substitute for sustained "contact" with nature or contact in a space less lopsided that than of the Forest. I explore how staff, whose experiences with the Lorikeets are qualitatively different than that of guests, develop intersubjective relationships with the birds.

Milton (2002), as previously detailed, argues that experiences with nature are essential if humans are to develop an empathic understanding of other living beings and the environment. She notes, "And, as we have seen, a consequence of identification with other entities is assumed to be that people will feel inclined to act benevolently toward them." (2002: 84) In problematizing the term "anthroporphism", she conceptualizes "egomorphism", which occurs when people perceive nonhuman animals as "like me" (based on experiences with them), rather than "human-like" (based on an attribution of characteristics) (2005: 261). However, in extending intersubjectivity and personhood to interspecies relationships, Milton does not address two aspects that I discuss in detail below:

(1) the impact of the quality or kinds of interactions humans have with animals in particular spaces

(2) the human capacity (or lack thereof) to identify with the violent and "unpleasant" aspects of nature, such as Lorikeet biting.

Through egomorphism, Milton argues that as long as nonhuman animals appear to share mutual understandings, our own sense of personhood and their sense of personhood can be developed (Milton 2005). This seems to suggest that humans may form egomorphic relationships with nonhumans, irrespective of the environment in which the interaction occurs. Following this line of reasoning, in the Forest, where bird bodies are regulated in order to cater to the advanced liberal consumer of edutainment, it might be possible for guests to locate personhood in the Lorikeets through their personal experiences with them (Rose 1996). I contend, however, that development of personhood with nonhumans is impacted by the quality of experiences people have with the nonhuman world. That is, the institutional governing that occurs through the advanced liberal strategies described previously, constructs an entirely anthropocentric encounter where guests are unlikely to develop egomorphic relationships with the Lorikeets (Foucault 2008; Rose 1996).

Understanding whether or not humans can see other beings as "like me" that may cause them harm or remind them of their own sometimes violent and predatory nature also has significant consequences for nature protection, given that people frequently cite desiring to save those animals most like humans, i.e. the charismatic megafauna. (Rolston 2002; Small 2012). Rose, the staff member in the Forest savagely and

Pachirat (2011) in Every twelve seconds. There, concealment and visibility worked in concert to produce animal bodies as food for human consumption. 
repeatedly bitten by a Lorikeet nesting in a brood box, serves as an example of how Aquarium staff can develop empathic, emotional, and intersubjective relationships with animals, despite exposure to their brutality and despite not viewing their actions as "like me." Rose grounds her intersubjectivity with the Lorkeets in a lack of physical interaction, whereby she and the birds live mutually undisturbed. She couples this lack of interaction with respect for them as living beings not "like me", but as romanticized wild "others." In contrast, Jennie, the staff member working regularly and directly with the Lorikeets, derives her intersubjectivity from ongoing, sustained relationships with them where she sees them as "like me", despite the Lorikeets regularly defecating on her and biting her. In a follow-up interview with Jennie, which began with her proudly displaying a large wound on her hand resulting from an encounter with a nesting pair of birds she commented, "You get much more, day-to-day [in Husbandry], and you get to know the animals and you develop relationships with them." For Jennie, the Lorikeets are "like me" because of their "positive" characteristics (they "love" each other, they are identifiable and have names, they feel pain) and "negative" characteristics (they bite and defecate). Rose's case suggests that intersubjectivity is not predicated on personhood or egomorphism and that violence (biting) can preclude a human from seeing an animal as "like me." Jennie's case intimates the opposite-her intersubjective relationship with the Lorikeets derives from her ability to view them as persons despite regular exposure to life's unpleasant aspects (biting, defecating).

Many staff working directly with the birds in the Forest, like Jennie, do develop ongoing relationships with them. One afternoon there, Justin, a staff member, brought me over to where a few Husbandry folks interacted with birds near the Hut. Below is an excerpt from my fieldnotes from that day:

\section{Excerpt 1.7: November 8, 2012}

At the end of my time in there, Justin took me over to where some Husbandry staff were interacting with the birds. One of them (Cindy) was allowing one of the birds to kiss her on her mouth. It was obvious she genuinely cared for the little green bird. The look in her eyes as she glimpsed its face told a story about how her relationships with the birds were not sanitized theme-park interactions, but rather empathic (think "intersubjective") understandings of another creature. She then went right out to where some of the birds were perched on the trees and put them on her finger. I was a little shocked to see these kinds of body-to-body contact, given that there were many guests present in the Forest and guests, of course, are prohibited from having these kinds of interactions with the birds. Having been savagely bitten by a pet parrot years back, myself, and knowing that my husband got stitches in his face after his pet parrot ripped his lip open, I told her she was brave for letting the bird kiss her face. She snapped back that she just knows which ones she can allow to do that, indicating to me that her relationships with the birds involved more than just providing the necessary nutrition and shelter.

Just a few moments later, I overheard Justin talk to a group of boys that looked about 5 years old and appeared to be rough-housing:

\section{Excerpt 1.8: November 8, 2012}

Justin (to the boys): What is going to happen when you scare the birds? You think they have a sharp beak? You see how sharp their beaks are? You see these cuts and welts left on my hand? It's all from the birds. It's not a good idea. So, how about we don't try to scare the birds? It's not a good idea. Thank you.

Juxtaposing these two types of interactions reveals striking differences. While the Husbandry staff member allows the birds to kiss her face and has them perch on her finger, Justin, in order to ensure a safe interaction (for both the birds and the boys) and a satisfying guest experience free of bloody encounters with birds, disciplines the boys into either not interacting with the birds or into having only limited contact with them. In this way, the institution's need to commodify, sanitize, and regulate bird-human interactions limits the range of emotional experiences people can have with the Lorikeets. Cindy's case illustrates that staff, some trained in the science of husbandry, can develop emotional and intersubjective relationships with the 
animals. As Candea (2010) points out, the role of affect and emotion in the care of and scientific study of nonhuman animals has been constructed as an anthropomorphic hindrance to the development of scientific knowledge about other species. The current study suggests that emotion figures prominently into the development of empathic relationships with other species, allowing humans to come to "know" them in still bounded ways, but perhaps opening up the possibility for interspecies intersubjectivity.

It would seem, then, that in order to develop these emotional experiences, guests would have to have the kinds of ongoing, more loosely regulated relationships with the birds that some staff have. Jennie, a staff member, discussed these relationships in an interview:

\section{Excerpt 1.9: August 14, 2013}

Teresa: Could you talk a little about what you hope guests take away from their experience here?

Jennie: I, in general, particularly with the Lorikeets, hope that...my hope is that they find the wonder and the joy and excitement and the fun of just watching without feeling like they have to touch and hold and pick up. There's so much going on and there are so many little stories within stories of...the birds... and it would be so great if the guests, because we're there long stretches of time, would get to know the animals and see it. The guests are there for 15 minutes or a half hour. They don't get to really see what's really happening.

Later in the interview, when describing how her role in Husbandry differs from her role in Education, she explains:

Jennie: You get just much more, day-to-day [in Husbandry], and you get to know the animals and you develop relationships with them.

And later, she illustrates the depth of her coming to know the birds:

Jennie: We have all these little babies. Feathers, you remember Feathers?

Teresa: I remember Feathers.

Jennie: Feathers, Feathers had-Feathers is still the cutest bird in there, but Feathers now is all cuddly, and Feathers comes up, Feathers is in the Barn in these big walk-in flights, and Feathers comes up and Feathers will play and she gets your hand and you can hear Feathers over all the different birds, she has a different—it's a she by the way. I was sure she was a boy, but she's a girl. And she has this little melodic voice that you can hear very differently; and it's just so cute.

The preceding two excerpts demonstrate Jennie's commitment to knowing the Lorikeets as persons "like me." Jennie sees and comes to know the intricacies of Feathers' behaviors—playing, singing, and physically interacting. She does not attribute "cuteness", "playfulness", or "cuddliness" to Feathers' simply because she recognizes these behaviors as "cute", "playful", and "cuddly" in humans (which Milton would describe as anthropomorphic point of view due to the attribution of human characteristics), but due to her personal involvement with her, allowing her to come to know Feathers as "like me." Personally involved with them (essential to Milton's model) Jennie feels a range of both positive and negative emotions (joy, excitement, empathy, and sorrow), which collectively contribute to her attribution of personhood to the Lorikeets. For Jennie, a re-imagined guest experience would not necessarily entail a human-in-animal theme park interaction, rather a "getting to know" the Lorikeets as complex social persons.

In such a re-imagined space, guests might be encouraged to question why the Lorikeets are held captive, bird bodies might not be biopolitically regulated to heighten the guest experience and, as Milstein suggests they might participate in animal care and feeding and be exposed to ill or injured animals normally housed behind-the-scenes and out of view (Milstein 2009). Sick animals are typically hidden from visitors to ensure an entertaining experience (i.e. fiscal survivability) and so the animals can rehabilitate in a safe environment. ${ }^{22}$ Exposure to ailing animals, however, can facilitate intersubjective relationships with them, as

\footnotetext{
${ }^{22}$ Peace (2005) similarly finds that "death" and "killing" are taboo topics for whale watch guides in Australia who believe that tourists do not want to engage in conversations about such drab and depressing topics as death. This highlights the tension between entertainment and education that ecotourism sites face.
} 
my conversation with Jennie illustrated one day while we briefly chatted outside near the Shark Lagoon. When I approached her there, she was gazing upon an injured pigeon. Security was called to haul off the pigeon, as all were concerned for its wellbeing and that of guests. Several passerby questioned staff about the pigeon and staff became worried it would negatively affect the guest experience:

Excerpt 1.10: December $15^{\text {th }}, 2012$

When I walk up to the Shark Lagoon, Jennie is standing there looking at a sick pigeon sitting on the ground. It's between the far left pool and the center pool when facing the Shark Lagoon. Its feathers are ruffled, it looks "puffy" and it's not moving-all signs that it is ill, based on my many years experience raising birds as a young adult and teenage girl. She has a sad look on her face, as she is a bird person and really has empathy for them.

Teresa: It's sad. You don't want to just leave it there and have somebody accidentally hit it. Jennie: Obviously. Whatever happens to it is better than this.

Teresa: Poor guy.

Jennie: I've had two guests come up to me and say, "You've got a pigeon over here and it doesn't look good." And it's not a place where we want people to be feeling like that. We want them to have (inaudible). You know?

Security staff come by to pick up the injured animal. Jennie comforts a few children who are looking on with concerned faces. She reassures them that the man is going to get the bird help.

The above excerpts illustrate that guests feel compassion and concern for sick animals, as Jennie had to reassure several visitors that the staff would adequately care for the sick pigeon. Though the Aquarium imagines guest encounters with ill or injured animals as unfavorable from a neoliberal customer service standpoint ("It's not a place where we want people feeling like that"), these kinds of interactions could possibly invoke care, concern, and compassion for the animals not invoked by simply touching or feeding them.

Excerpt 1.11: December 15, 2012

A few minutes after the sick pigeon is carried away, I chat with Jennie about what it is like for her working behind the scenes with the Lorikeets

Jennie: Yeah. And I got a little eye opening yesterday to, you know, I'm all happy thinking I get to feed them and clean up. And I don't mind cleaning bird poop and all that stuff. Well, she [her supervisor] goes, now you've got to be honest with me. You're going to see a lot of stuff. They die and you care for them and they die and she goes, if it gets to be too much for you, tell me. Cuz I don't want you to feel really bad about it...And I thought, (inaudible) about the pigeon. So it's hard...because you get to know them [the Lorikeets]. You know their names. You-I just want the fun part.

In this last excerpt, Jennie connects her compassion for the birds directly to caring for them while they are ill. While she explains that she never thought about how overwhelming it might be to have to deal with the suffering or loss of an animal in her care, her empathy, compassion, and emotional attachment to the birds are bound up to the ways in which she sees them — as living beings who have identifiable features (the ability to suffer and feel pain when they are ill) and names (personhood). In this way, she enters into an intersubjective relationship with them, interacting through a "mutual understanding." (Milton 2005: 263). While we cannot know the degree to which the Lorikeets participate in this "mutual understanding" or intersubjective relationship, recall that Milton argues that whether or not animals actually involve themselves intersubjectively with humans is irrelevant; it only matters that they appear to do so (2005: 263). Though identification with animals based on their perceived personhood (or human-likeness) is an anthropocentric view, it nonetheless suggests the importance of the role of emotions and the recognition of personhood in 
nonhuman entities for some humans, particularly those who see themselves as caretakers of their nonhuman companions. ${ }^{23}$

\section{Theoretical implications}

This article has demonstrated that physical interactivity between nonhumans (i.e. wild animals) and humans in a space like the Aquarium necessitates different types of bioregulation when compared to spaces where nonhumans and humans do not physically interact. Theoretically, it suggests that researchers must continue to modify and reconfigure Foucault's original concepts (biopolitics and biopower) in order to understand the regulation of nonhuman bodies in institutional spaces where human-nonhuman entanglements are bound in complex ways to the fiscal survivability of an institution. In the Forest, for example, Lorikeet bodies are manipulated not only to "make live" in the Foucauldian conceptualization of the term, but also to financially benefit the institution vis-à-vis a heightened guest experience. At the Aquarium, then, biopolitics is as much about maintaining a healthy population of Lorikeets as it is with ensuring the "making live" of the institution.

Though governing in this space produces visitors as consumers of animal bodies, Kay Milton's theories-person-based identification and egomorphism—suggest that personal experiences with the nonhuman entities matter with respect to inspiring humans to care and to be empathic toward nonhumans (Milton 2002, 2005). Since staff at the Aquarium develop intersubjective relationships with the birds as they have both positive and negative personal experiences with them, there exists the potential for guests to have intersubjective relationships as well. This would require, however, the enactment of governing that is less focused on constructing neoliberal consumers, and aimed instead at exploring the possibilities for empathy, compassion, and care.

\section{References}

Anderson, W. 1995. Excremental colonialism: public health and the poetics of pollution. Critical Inquiry 21(3): 640-669.

Beardsworth, A. and A. Bryman. 2001. The wild animal in late modernity: the case of the Disneyization of zoos. Tourist Studies 1(1): 83-104.

Callon, M. 1986. Some elements of a sociology of translation: domestication of the scallops and the fisherman of St. Brieuc Bay. In J. Law (ed.) Power, action, and belief: a new sociology of knowledge? London: Routledge. Pp196-223.

Candea, M. 2010. "I fell in love with Carlos the meerkat:" engagement and detachment in human-animal relations. American Ethnologist. 37(2): 241-258.

Carrier, J. G. 2012. Dollars making sense: understanding nature in capitalism. Environment and Society: Advances in Research 3: 5-18.

Chrulew, M. 2011. Managing love and death at the zoo: the biopolitics of endangered species preservation. Australian Humanities Review 50: 137-157.

Curtis, V. and A. Biran. 2001. Dirt, disgust, and disease: Is hygiene in our genes? Perspectives in Biology and Medicine 44(1): 17-31.

Desmond, J.C. 1999. Staging tourism: bodies on display from Waikiki to Sea World. Chicago: University of Chicago Press.

Devall, B. and G. Sessions. 1985. Deep ecology: living as if nature mattered. Salt Lake City: Peregrine Smith Books.

Douglas, M. 1966. Purity and danger. London: Routledge and Kegan Paul.

Elias, N. 1994. The civilizing process. Oxford: Blackwell.

\footnotetext{
${ }^{23}$ I italicize "some" here to highlight that not all volunteers at the Aquarium necessarily recognize this personhood in animals. Recall that Rose described them as wild animals, who do what wild animals do.
} 
Fletcher, R. 2010. Neoliberal environmentality: towards a postructuralist political ecology of the conservation debate. Conservation and Society 8(3): 171-181.

Foucault, M. 1978. The history of sexuality volume 1: an introduction. New York: Vintage Books.

Foucault, M. 1991. Governmentality. G. Burchell, C. Gordon, and P. Miller (eds.). Chicago, IL: University of Chicago Press.

Foucault, M. 2003. Society must be defended. M. Bertani and A. Fontana (ed.). New York, NY: Picador.

Foucault, M. 2007. Security, territory, population. New York, NY: Picador.

Foucault, M. 2008. The birth of biopolitics. M. Senellart (ed.). G. Burchell (trans.). New York, NY: Picador.

Fox, W. 1995. Toward a transpersonal ecology: developing new foundations for environmentalism. New York: State University of New York Press.

Haraway, D. J. 1989. Primate visions. New York: Routledge.

Haraway, D.J. 2008. When species meet. Minneapolis: University of Minnesota Press.

Kirksey, S.E. and S. Helmreich. 2010. The emergence of multispecies ethnography. Cultural Anthropology 25(4): 545-476.

Knight, J. 2005. Feeding Mr Monkey: cross-species food 'exchange' in Japanese monkey parks. In J. Knight (ed) Animals in person: cultural perspectives on human-animal intimacies. New York, NY: Berg. Pp. 231-253.

Latour, B. 1987. Science in action: how to follow scientists and engineers through society. Cambridge: Harvard University Press.

Lemke, T. 2001. 'The birth of bio-politics': Michel Foucault's lecture at the Collège de France on neoliberal governmentality. Economy and Society 30(2): 190-207.

Luke, T.W. 2000b. The Missouri Botanical Garden: reworking biopower and florapower. Organization and Environment 13(3): 305-321.

Luke, T.W. 2000a. Beyond birds: biopower and birdwatching in the world of Audubon. Capitalism Nature Socialism 11(3): 7-37.

Marietta, D.E. 1995. For people and the planet. Philadelphia: Temple University Press.

Massam, M. and Mawson, P. 2009. Battling bird damage. Australian Viticulture 13(6): 16-23.

Milton, K. 2002. Loving nature: towards an ecology of emotion. New York: Routledge.

Milton, K. 2005. Anthropomorphism or egomorphism? The perception of non-human persons by human ones. In J. Knight (ed.) Animals in person: cultural perspectives on human-animal intimacies. New York: Berg. Pp255-269.

Milstein, T. 2009. "Somethin' tells me it's all happening at the zoo": discourse, power, and conservationism. Environmental Communication 3(1): 25-48.

Ogden, L.A., Hall, B., and K. Tanita. 2013. Animals, plants, people, and things: a review of multispecies ethnography. Environment and Society: Advances in Research 4: 5-24.

Pachirat, T. 2011. Every twelve seconds. New Haven: Yale University Press.

Peace, A. 2005. Loving leviathan: the discourse of whale watching in Australian ecotourism. In J. Knight (ed.) Animals in person: cultural perspectives on human-animal intimacies. New York: Berg. Pp191210.

Pedersen, H. 2011. Counting affects: Mo[ve]ments of intensity in critical avian education. Canadian Journal of Environmental Education 16: 14-28.

Rabinow, P. 2010. Introduction. In P. Rabinow (ed) The Foucault reader. New York, NY: Vintage Books. Pp3-29.

Rabinow, P. and N. Rose. 2006. Biopower today. Biosocieties 1(2): 195-217. version

Rolston, H. 2002. From beauty to duty: Aesthetics of nature and environmental ethics. In A. Berleant, (ed.) Environment and the arts: perspectives on environmental aesthetics. Hampshire and Burlington: Aldershot. Pp127-141.

Rose, N. 1993. Government, authority, and expertise in advanced liberalism. Economy and Society 22(3): 283-299. 
Rose, N. 1996. Governing "advanced" liberal democracies. In A. Barry, T. Osborne, and N. Rose (eds) Foucault and political reason. Chicago, IL: The University of Chicago Press. Pp. 37-64.

Rutherford, S. 2011. Governing the wild: ecotours of power. Minneapolis: University of Minnesota Press.

Small, E. 2012. The new Noah's Ark: beautiful and useful species only. Part 2. The chosen species. Biodiversity 13(1): 37-53.

Spradley, J. P. 1979. The ethnographic interview. New York: Holt, Rinehart and Winston.

Watson, R. 2008. A critique of anti-anthropocentric ethics. In L.P. Pojman and P.Pojman (eds.) Environmental ethics: readings in theory and application. $\left(5^{\text {th }}\right.$ ed) Belmont: Wadsworth/Thomson Learning. Pp162-167.

Weikel, D. 2000a. Aquarium gets state aid as revenue drops. Los Angeles Times July 1.

Weikel, D. 2000b. Financially troubled aquarium seeks to refinance debt. Los Angeles Times Nov. 22.

Williams, R. 1980. Problems in materialism and culture. London: Verso. 